\title{
Dossî́
}

\section{Evangelização e pluralismo religioso na escola católica: vias para um diálogo evangelizador e inclusivo}

\author{
Osmar Aloizio Resende ${ }^{1}$ \\ Diogo Marangon Pessotto ${ }^{2}$
}

Resumo: É possível, na escola católica, um diálogo entre as expressões religiosas que seja, ao mesmo tempo, evangelizador e inclusivo? O presente trabalho busca analisar os conceitos de pluralismo religioso e diálogo inter-religioso, vinculando-os ao processo educativo-evangelizador, a fim de apontar os principais desafios e alguns caminhos para um processo evangelizador em diálogo. $\mathrm{O}$ estudo, exploratório e qualitativo, tem como base a pesquisa documental e bibliográfica. Quanto aos contextos do pluralismo religioso, o referencial caracteriza a modernidade e a pós-modernidade em sua relação com a religião e a evangelização. Sanchez (2010), Libânio (1998), Martelli (1995) e Miranda (2006) auxiliam na reflexão. Quanto aos conceitos, adequado delineamento sobre o diálogo inter-religioso é apresentado na Declaração Nostra Aetate (1965) do Concílio Vaticano II e em alguns documentos eclesiais recentes, como Diálogo e Anúncio (1991). Quanto às práticas, articulam-se os princípios do diálogo inter-religioso com o processo educativo-evangelizador por meio de vias de diálogo. Colet e Wolff (2015) e o magistério do Papa Francisco problematizam e abrem horizontes para a questão. Conclui-se, pois, que a escola católica é um espaço privilegiado para o diálogo entre as expressões religiosas, o que não só afirma a identidade do projeto educativo-evangelizador como também o traduz em itinerários de diálogo e evangelização.

Palavras-chave: Escola católica. Evangelização. Pluralismo religioso. Diálogo inter-religioso. Vias.

\section{Evangelization and religious pluralism in catholic schools: ways to an inclusive and evangelizing dialogue}

\begin{abstract}
Is it possible, in the Catholic school, a dialogue between religious expressions that is at the same time evangelizing and inclusive? The present work seeks to analyze the concepts of religious pluralism and interreligious dialogue, linking them to the educational-evangelizing process, in order to point out the main challenges and some paths to an evangelizing process in dialogue. The exploratory and qualitative study is based on documental and bibliographic research. As for the contexts of religious pluralism, the referential characterizes modernity and postmodernity in its relationship with religion
\end{abstract}


and evangelization. Sanchez (2010), Libânio (1998), Martelli (1995) and Miranda (2006) help us in the reflection. As for the concepts, a suitable design for interreligious dialogue is presented in the Second Vatican Council's Declaration Nostra Aetate (1965) and in recent ecclesial documents, such as Dialogue and Proclamation (1991). As for the practices, the principles of interreligious dialogue are articulated with the educational-evangelizing process through means of dialogue. Colet and Wolff (2015) and the teaching of Pope Francisco problematize and open horizon to the question. It is concluded, therefore, that the Catholic school is a privileged space for dialogue between religious expressions, which not only affirms the identity of the educative-evangelizing project but also translates it into itineraries of dialogue and evangelization.

Keywords: Catholic school. Evangelization. Religious pluralism. Interreligious dialogue. Roads.

\section{Evangelización y pluralismo religioso en la escuela católica: caminos para un diá- logo evangelizador e inclusivo}

Resumen: ¿Es posible, en la escuela católica, un diálogo entre las expresiones religiosas que sea al mismo tiempo evangelizador e inclusivo? El presente trabajo busca analizar los conceptos de pluralismo religioso y diálogo interreligioso, vinculándolos al proceso educativo-evangelizador, a fin de apuntar los principales desafíos y algunos caminos hacia un proceso evangelizador en diálogo. El estudio, exploratorio y cualitativo, tiene como base la investigación documental y bibliográfica. Mientras que en los contextos del pluralismo religioso, el referencial caracteriza la modernidad y la posmodernidad en su relación con la religión y la evangelización. Sanchez (2010), Libânio (1998), Martelli (1995) y Miranda (2006) nos ayudan en la reflexión. Ya en los conceptos, adecuado de lineamiento sobre el diálogo interreligioso se presenta en la Declaración Nostra Aetate (1965) del Concilio Vaticano II y algunos documentos eclesiales recientes, como Diálogo y Anuncio (1991). Ya en las prácticas, se articulan los principios del diálogo interreligioso con el proceso educativo-evangelizador por medio de vías de diálogo. Colet y Wolff (2015) y el magisterio del Papa Francisco problematizan y abren horizontes para la cuestión. Se concluye que la escuela católica es un espacio privilegiado para el diálogo entre las expresiones religiosas, lo que no sólo afirma la identidad del proyecto educativo-evangelizador, sino que lo traduce en itinerarios de diálogo y evangelización. Palabras-clave: Escuela católica. Evangelización. Pluralismo religioso. Diálogo interreligioso. Caminos.

\section{Introdução}

É possível, na escola católica, a constituição de um diálogo evangelizador e inclusivo entre as expressões religiosas? Com essa motivação, a proposta foi analisar os conceitos de pluralismo religioso e diálogo inter-religioso, vinculando-os ao processo educativo-evangelizador, a fim de apontar os principais desafios e alguns caminhos para um processo evangelizador em diálogo. A relevância da questão está no fato de que a educação evangelizadora se dá em um contexto de pluralismo 
religioso. Um projeto educativo-evangelizador destinado apenas aos cristãos e/ou católicos estaria mutilado, pois seu caráter integral propõe os sentidos, os valores e as experiências do Evangelho a todos. Por isso, a análise contextual, conceitual e operacional da relação entre educação, evangelização e pluralismo é indispensável para que polarizações e reducionismos não a comprometam, por causa de confusa compreensão, fechamento identitário ou homogeneidade estéril.

\section{Pós-modernidade, pluralismo religioso e evangelização}

\section{Modernidade: deslocamento da religião}

A ideia de transformação é central para a compreensão da modernidade. Em primeiro lugar, como condição de possibilidade para novas formas de viver e representar a realidade. Em segundo lugar, de acordo com Sanchez (2010), como processo de transitoriedade e ruptura e como esfacelamento do sentido de continuidade histórica. O conceito de secularização e o binômio razão-subjetividade expressam a noção moderna de transformação em termos religiosos.

Quanto à secularização, tem-se que é o processo em que a religião não é mais o principal critério para a compreensão do mundo. "Do ponto de vista político-institucional, a Igreja Católica Romana perde o lugar de matriz religiosa e tem seu papel político diminuído" (SANCHEZ, 2010, p. 30). Consequências disso foram a separação Igreja-Estado e a progressiva autonomia das instâncias sociais em detrimento da esfera religiosa. Para Marramao (1994), o principal aspecto da secularização é a ruptura do monopólio de interpretação do mundo pela Igreja. A autonomização do social se dá pela afirmação do sujeito, o qual, valendo-se da razão instrumental, racionaliza sua compreensão de mundo, controla a realidade e domina a sociedade, sem recorrer à religião, cujo papel fora transferido para a ciência.

Considerando tal ruptura, Touraine (1997, p. 218) indica que "não existe uma figura única da modernidade, mas duas figuras voltadas uma para a outra e cujo diálogo constitui a Modernidade: a racionalização e a subjetivação". A fonte de sentido foi deslocada para o ser humano: não está mais em Deus, mas na razão como subjetividade. Se antes as normas e os sentidos eram ditados pelo transcendente das instituições religiosas, agora é a racionalidade que ordena as escolhas.

Acreditava-se que, com a modernidade, a religião desapareceria aos poucos. Contudo, a pós-modernidade se deu na contramão dessa pretensão arreligiosa.

Pós-modernidade: o retorno do religioso

O conceito de pós-modernidade faz referência à época presente como catastrófica. Os mitos modernos foram destruídos, pois só trouxeram o 
desencanto. Restam o pragmatismo cotidiano, a fragmentação social e a experiência emocional dos indivíduos. O capitalismo, pautado na razão técnica e na autonomia do sujeito, levou ao vazio. O projeto pós-moderno é a criação de um novo mundo do nada, sem princípios e fins, no qual o valor é a ausência de valores.

No âmbito religioso, para Libânio (1998), a religião pós-moderna exerce no sujeito uma função terapêutica: resignação, alívio e uma gama de fantasias diante das adversidades sociais e da vida. Nesse sentido, presencia-se o retorno do religioso ${ }^{3}$, que ressignifica os princípios modernos da individualização, da subjetivação e da privatização da religião. "O surto do sagrado é uma outra face da secularização da sociedade moderna e pós-moderna e não sua negação" (LIBÂNIO, 1998, p. 61).

Proclamou-se o "fim do monopólio das tradições religiosas". [...]. Já não são as Igrejas ou religiões institucionais que criam necessariamente o espaço da experiência religiosa. Antes, pelo contrário, elas perdem força e deixam o sagrado solto, entregue às vivências pessoais, individuais em processo crescente de privatização e individualização (LIBÂNIO, 1998, p. 61).

A pós-modernidade é o período das novas formas religiosas. "Contrariamente ao pensamento clássico marxista que assegurava o fim da religião, as interpretações atuais afirmam a substituição de uma situação inicial de monopólio religioso por uma outra de pluralismo" (MÓNICO, 2015, p. 2075). Com isso, Libânio (1998) afirma uma inversão na relação sagrado-secularização: a secularização subjetiva privatiza o religioso. A sensação é de inundação religiosa, de caráter imanente.

$\mathrm{Na}$ esteira de Peter Berger, Martelli (1995) afirma que as consequências do pluralismo religioso são comparadas às do livre mercado para a economia, dando origem ao mercado religioso. "No plano individual, a secularização é a perda de plausibilidade da religião institucional pela visão do mundo pessoal" (MARTELLI, 1995, p. 292). O pluralismo religioso, então, não se identifica com discursos universais. Em geral, o indivíduo escolhe crenças e valores contraditórios entre si.

Há autores que veem aí uma nova fase da secularização moderna. Segundo Martelli (1995), na pós-modernidade, a secularização se esgota. O pós-moderno não traz as oposições da modernidade. É, antes, pós-secular, dessecularização. Nesse sentido, o futuro da religião está na vitalidade das pequenas comunidades emocionais religiosas (Hervieu-Lègier); ou ainda, a religião continua a existir na pós-modernidade como depósito cultural de símbolos e crenças (Vattimo); e, por fim, a religião católica é antimoderna porque é ultramoderna, dizendo algo do homem para o homem, com sentido e em diálogo (Maritain). 
Em suma,

tanto mais forte é esse surto religioso privatizado e individualizado quanto mais a modernidade se caracteriza pelo movimento de pluralização, gerando os mais diversos pluralismos. As ofertas crescem. As possibilidades de escolha aumentam. E também as combinações religiosas possíveis são ilimitadas (LIBÂNIO, 1998, p. 62).

Logo, o pluralismo religioso diz das experiências vivenciadas tanto nas grandes religiões como nas novas formas religiosas sincréticas. Individualismo e combinações religiosas constituem o pluralismo religioso pós-moderno.

Evangelização e pluralismo religioso: contextos e desafios

Para Miranda (2006), a Igreja não dialogou efetivamente com a sociedade moderna. Por sua vez, a sociedade pós-moderna não oferece respostas às questões humanas fundamentais. Em contrapartida, a modernidade - com os avanços científicos e o respeito à liberdade religiosa - e a pós-modernidade - com o retorno do religioso e a valorização das diferenças - formam um contexto sociocultural de abertura para a evangelização. Nesse sentido, as épocas de crise são uma oportunidade de reavaliação e criatividade quanto ao modo de ser Igreja. Com isso,

também o cristão, embora reconheça ter uma vocação meta-histórica, que o faz viver diferentemente neste mundo, não deixa de ser deste mundo [...]. Desse modo é sempre a partir de uma realidade concreta que deve viver sua fé. Nessa realidade que constitui o seu mundo [...] se encontra não só determinada sociedade, mas também determinada configuração eclesial, determinada expressão teológica, determinada ação pastoral, todas intimamente conexas e se apoiando mutuamente (MIRANDA, 2006, p. 193).

A marca da cristandade torna o pluralismo religioso um desafio para a evangelização. Naquele período, de Constantino a meados do século XX, o Estado e a Igreja detinham a palavra, e a doutrina católica era a referência para a organização social. "A quase ausência de sérios desafios não estimulava seja um questionamento, seja um aprofundamento dela. Tudo era aceito, [...] já que pertencia à cultura hegemônica da época” (MIRANDA, 2006, p. 197). Por essa influência, a evangelização, em muitos casos, apresenta-se como manutenção da comunidade eclesial exclusivamente pela moral e pela distribuição dos sacramentos.

Outro desafio premente: rejeitar as expressões autênticas do cristianismo em prol de uma homogeneidade das expressões religiosas. Isso seria prescindir do testemunho vivo das comunidades animadas pelo Espírito. "[...] não se pode silenciar a particularidade das verdades e das práticas cristãs, diluindo o cristianismo no que dele foi acolhido pela cultura ocidental” (MIRANDA, 2006, p. 265). 
Nesse sentido, "como pode a fé cristã ser acolhida numa sociedade onde reina o pluralismo de concepções de vida e de definições de realidade?" (MIRANDA, 2006, p. 265). A fé cristã não pode renunciar à salvação que oferece a todos. Por isso, para Miranda (2006), dois desafios sintetizam as interpelações do pluralismo religioso à fé cristã: 1) o desafio teológico. Como pode o cristianismo pleitear a salvação de todos em Cristo, se agora se vive em um ambiente religioso plural, de diferentes e contraditórios caminhos de salvação?; 2) o desafio pastoral. O pluralismo e a diversidade não permitem considerar um cristianismo monolítico e homogeneizante. Por isso, o desafio pastoral está especialmente no campo da evangelização, em uma ação pastoral atenta às exigências e às complexidades atuais.

\section{Teologia das religiões}

O desafio teológico se refere à universalidade da salvação em Cristo. Nesse sentido, a Igreja se questiona sobre sua relação com as religiões não cristãs, sem abdicar da verdade cristã. O posicionamento teológico eclesial sobre tal relação se expressa em uma teologia das religiões, que articula evangelização e diálogo.

\section{Teologia das religiões e modelos teológicos}

A teologia das religiões se desenvolveu amplamente a partir do Concílio Vaticano II. Segundo Miranda (1994), resulta da proximidade entre cristianismo e religiões, do testemunho dos membros das religiões, da relativização religiosa, da relação missão-pluralismo. Discute "se uma religião é depositária da revelação e se pode ser considerada mediação salvífica” (MIRANDA, 1994, p. 11).

Para fugir de um certo dogmatismo, que esteve, por vezes, presente na reflexão cristã do passado, buscam-se padrões "de fora" que permitam avaliar a verdade de uma religião. [...]. Neste sentido teremos sempre uma pluralidade de teologias das religiões, elaboradas a partir de pressupostos diferentes (MIRANDA, 1994, p. 11).

Para Miranda (1994), isso exige do cristianismo uma autocompreensão quanto à sua pretensão de verdade e universalidade e a busca de sentido, função e valor das religiões na história da salvação. Quanto aos modelos teológicos que tratam do valor salvífico das religiões, tem-se uma divisão tripartita.

O eclesiocentrismo afirma a exclusividade da salvação operada por Cristo na Igreja. Segundo Ferreira (2009) ${ }^{4}$, o conhecimento cristão de Deus é o único válido nesse caso, para o qual está fora da salvação quem não admite a revelação. Contudo, não se justifica tal radicalismo. A participação da Igreja no plano da 
salvação "se dá por meio de sua presença no mundo, da palavra proclamada, dos sacramentos celebrados e do testemunho coerente e eficaz" (FERREIRA, 2009, p. 6). Se Cristo é a salvação, a Igreja é "sacramento da salvação", servidora de Cristo.

O cristocentrismo, de acordo com Miranda (1994), aceita a salvação nas outras religiões, mas não sua autonomia salvífica. Tal posição procura "conciliar a vontade salvífica universal de Deus com o fato de que todo homem vive e se realiza como homem dentro de uma tradição cultural, que tem na religião respectiva sua expressão mais elevada e sua fundamentação última" (MIRANDA, 1994, p. 13). Esse modelo teve no Concílio Vaticano II espaço privilegiado para seu desenvolvimento na teologia católica. A noção de "hierarquia de verdades" do Decreto Unitatis Redintegratio (CONCÍLIO ECUMÊNICO VATICANO II, 2004, n. 11) indicou o mistério de Cristo como critério primordial para a gradação dos dogmas da fé. Assim, as religiões relacionam-se com o mistério de Cristo em primeiro lugar e só depois com o mistério da Igreja. Acerca da unicidade e da universalidade da salvação em Jesus Cristo, Miranda (1994) entende ser seu fundamento o mistério da encarnação. O Cristo encarnado é a plenitude da revelação, a verdade definitiva da fé. Portanto, o cristocentrismo postula a participação e a inclusão das religiões na única e universal salvação em Cristo pelos valores e pelas práticas consonantes com o Evangelho, vivenciados com retidão e sinceridade por seus membros, alcançados, por isso, pela graça redentora.

Já o teocentrismo visa à superação do cristocentrismo por meio de duas posições. Para a primeira, segundo Miranda (1994), Jesus Cristo é o paradigma dos mediadores de salvação, mas não o único. Se Cristo não tivesse existido, não se ficaria sem a salvação, mas apenas sem seu mediador perfeito. Para a segunda, Cristo não é reconhecido como "constitutivo nem como normativo para a salvação do homem” (MIRANDA, 1994, p. 14). Não se pode julgar os desígnios salvíficos de Deus e o valor de salvação das religiões. Seguindo Miranda (1994), toda religião tem a mesma finalidade para o teocentrismo. Deus em si é inacessível; conhece-se dele o que se manifesta na experiência humana transcendente e nas imagens de Deus. Para Miranda (1994), o teocentrismo é insuficiente ao afirmar uma noção indeterminada de Deus, ao passo que, segundo Ferreira (2009), para muitos teólogos dessa linha, um ser histórico e condicionado, Jesus Cristo, não pode ter relevância universal. Desse modo, propõe-se um pluralismo de princípio: Deus quis todas as religiões como caminhos autônomos de salvação. A verdade passa, então, por uma religião de estados de ânimo subjetivos. Dada a relatividade das experiências, seu critério é pragmático e terapêutico, imanentista.

\section{O Concílio Vaticano II}

Uma das questões referidas à Igreja no Concílio Vaticano II era a da sua relação com as religiões não cristãs e as diversas expressões religiosas ${ }^{5}$. Para 
isso, o Concílio redigiu três documentos que preconizam o diálogo, a relação, a cooperação e a comunhão: Decreto Unitatis Redintegratio, sobre a unidade cristã; Declaração Dignitatis Humanae, sobre a liberdade religiosa; e Declaração Nostra Aetate, sobre o diálogo inter-religioso. Deter-se-á nesta última, ciente de que uma recepção plena do Concílio Vaticano II privilegia o ser dialogal e relacional da Igreja.

A redação de Nostra Aetate nasceu do Decreto sobre os judeus e demais não cristãos, de 1964. Definiu-se o documento como Declaração, tratando das grandes religiões, em especial do Judaísmo. Também razões teológicas motivaram tal opção, pois o texto deveria se articular com os demais textos conciliares. A Declaração, texto mais breve do Concílio, foi promulgada em 28 de outubro de 1965. Não era programática, mas de intenções: “a Igreja deseja aproximar-se das religiões, para promover o diálogo e a mútua colaboração” (MAÇANEIRO, 2014, p. 1) ${ }^{6}$. Para Usarski (2015), Nostra Aetate tem uma retórica construtiva, que se concentra nos elementos de santidade e verdade das religiões, e não nas discordâncias. Afirma, pois, a necessidade de a Igreja dar maior atenção à sua relação com as religiões por meio de uma revisão eclesial. A origem e o fim do ser humano estão em Deus, "que a todos estende a sua providência, seus testemunhos de bondade e seus desígnios de salvação até que os eleitos se reúnam na cidade santa, iluminada pela glória de Deus e onde todos os povos caminharão na sua luz" (CONCÍLIO ECUMÊNICO VATICANO II, 1965, n. 1). Deus dispõe tais auxílios pela riqueza multiforme da graça na história. Logo, as religiões inserem-se no único plano salvífico. Esses auxílios são caminhos para o Absoluto, na verdade e na prática do bem. A Declaração também afirma o senso religioso dos povos, por meio do qual reconhecem a divindade na vida e nos fatos. As religiões são modos de viver que surgem do senso religioso, em conexão com a cultura, estruturando-se por noções apuradas e linguagem própria (CONCÍLIO ECUMÊNICO VATICANO II, 1965, n. 2).

Por essa razão, a Igreja "nada rejeita do que nessas religiões existe de verdadeiro e santo” (CONCÍLIO ECUMÊNICO VATICANO II, 1965, n. 2), ainda que haja incompatibilidades doutrinais. Contudo, anuncia Cristo como plenitude, o que lhe exige o diálogo e a colaboração com as religiões, de modo que os seus filhos deem "testemunho da vida e fé cristãs, reconheçam, conservem e promovam os bens espirituais e morais e os valores sócio culturais que entre eles se encontram" (CONCÍLIO ECUMÊNICO VATICANO II, 1965 , n. 2). São apresentados os elementos de santidade e verdade das religiões hindu, budista, autóctones, muçulmana e judaica (CONCÍLIO ECUMÊNICO VATICANO II, 1965, n. 2,3,4).

Eis algumas conclusões de Nostra Aetate: 1) reconhecimento da função antropológica das religiões e seus valores: acolhida do mistério, sacralidade, ascese, oração, busca pelo definitivo; 2) ênfase no aspecto pastoral e propositivo e 
em uma renovada atitude eclesial em relação às religiões; 3) o olhar positivo das religiões; 4) o diálogo e a colaboração pela paz; 5) o anúncio de Cristo no diálogo e no respeito.

\section{Diálogo e Anúncio}

O documento Diálogo e Anúncio, publicado em 1991 pela Congregação para a Evangelização dos Povos e Pontifício Conselho para o Diálogo Inter-Religioso, trata do diálogo inter-religioso e do anúncio de Cristo, recuperando os ensinamentos conciliares ${ }^{7}$ e os documentos papais posteriores ${ }^{8}$. A adequada compreensão do diálogo inter-religioso, o equilíbrio entre diálogo e anúncio, o pluralismo religioso e as iniciativas religiosas conjuntas motivaram a redação de tal documento doutrinal e pastoral. $\mathrm{O}$ texto considerou as religiões que fazem referência à fé de Abraão, como o Cristianismo, e as grandes religiões. Os novos movimentos religiosos não foram incluídos, mas a doutrina pastoral do documento orienta o diálogo nesse âmbito (CONGREGAÇÃO PARA A EVANGELIZAÇÃO DOS POVOS; PONTIFÍCIO CONSELHO PARA O DIÁLOGO INTER-RELIGIOSO, 1991).

Sobre Diálogo e Anúncio, Maçaneiro (2014, p. 1) afirma que, "ao considerar a interação diálogo-anúncio na missão evangelizadora, ele enfoca de modo privilegiado a questão soteriológica, no âmbito das religiões". Por isso, a unidade do plano da salvação em Cristo é a condição para o diálogo. De outro modo, o evento Cristo é abertura, e não obstáculo, ao diálogo. Ademais, a consideração positiva das religiões supõe um "estreito contato com elas" por meio do diálogo e da "correta avaliação teológica destas tradições" (CONGREGAÇÃO PARA A EVANGELIZAÇÃO DOS POVOS; PONTIFÍCIO CONSELHO PARA O DIÁLOGO INTER-RELIGIOSO, 1991, n. 14). Reafirmam-se, com isso, os valores humanos e espirituais das religiões. A salvação em Cristo "através de caminhos misteriosos" (CONGREGAÇÃO PARA A EVANGELIZAÇÃO DOS POVOS; PONTIFÍCIO CONSELHO PARA O DIÁLOGO INTER-RELIGIOSO, 1991, n. 15) é, pois, universal. Isso vale, de acordo com o Gaudium et Spes 22,

[...] para todos os homens de boa vontade, no coração dos quais [...] opera a graça. [...], se Cristo morreu por todos e a vocação última do ser humano é realmente uma só, a saber, divina, nós devemos acreditar que o Espírito Santo oferece a todos [...] serem associados ao mistério pascal (CONCÍLIO ECUMÊNICO VATICANO II, 2007, GS 22).

João Paulo II (1986, n. 53) diz da ação universal do Espírito Santo no mundo antes do Evangelho e também fora da Igreja visível. Tal ação se re- 
fere à presença misteriosa do Espírito no coração humano. Com isso, a base teológica do diálogo inter-religioso é cristológico-pneumatológica. A unidade da salvação se dá em Cristo, no Espírito, cuja ação misteriosa opera também naqueles que desconhecem a Cristo. A prática dos valores de suas religiões e o seguimento de sua consciência são respostas positivas dos membros das religiões à salvação.

A relação Igreja-Reino de Deus também é pressuposto do diálogo inter-religioso, pois evidencia o caráter cristológico e inclusivo da salvação. A Igreja é germe do Reino, anuncia-O e aspira à sua perfeição definitiva, sendo que:

\begin{abstract}
os membros das outras tradições religiosas são ordenados ou orientados [...] para a Igreja, enquanto ela é o sacramento em que o Reino de Deus está "misteriosamente" presente, pois, à medida que eles respondem à chamada de Deus, sentida na sua consciência, são salvos em Jesus Cristo e, por conseguinte, já compartilham, de qualquer modo, da realidade significada pelo Reino (CONGREGAÇÃO PARA A EVANGELIZAÇÃO DOS POVOS; PONTIFÍCIO CONSELHO PARA O DIÁLOGO INTER-RELIGIOSO, 1991, n. 35).
\end{abstract}

Nesse caminho, a Igreja avança em busca da plenitude da verdade, firmando um diálogo de salvação com todos, à luz do diálogo que Deus estabelece ao longo dos tempos com a humanidade, oferecendo-lhe a salvação (CONGREGAÇÃO PARA A EVANGELIZAÇÃO DOS POVOS; PONTIFÍCIO CONSELHO PARA O DIÁLOGO INTER-RELIGIOSO, 1991, n. 38).

Entre as formas do diálogo, há: a) diálogo da vida, aberto, solícito, na partilha das alegrias e das tristezas; b) diálogo das obras, na colaboração com o desenvolvimento humano integral; c) diálogo dos intercâmbios teológicos, para a compreensão das heranças e dos valores religiosos; d) diálogo da experiência religiosa, pela partilha das riquezas espirituais. O diálogo possui um sentido concreto e deve ser meio para a luta em favor dos direitos humanos, da justiça e da paz (CONGREGAÇÃO PARA A EVANGELIZAÇÃO DOS POVOS; PONTIFÍCIO CONSELHO PARA O DIÁLOGO INTER-RELIGIOSO, 1991, n. 42).

Quanto à relação diálogo-evangelização, Maçaneiro (2014) afirma que evangelizar em diálogo possibilita aos não cristãos explicitar a salvação recebida à luz do Evangelho. Por isso, diálogo e anúncio são faces da autêntica missão evangelizadora da Igreja. Convívio, partilha e cooperação não atenuam a mensagem cristã nem levam à abdicação da fé. Antes, são "método de presença, de respeito e de amor para com todos os homens" (CONGREGAÇÃ̂ PARA A EVANGELIZAÇÃO DOS POVOS; PONTIFÍCIO CONSELHO PARA O DIÁLOGO INTER-RELIGIOSO, 1991, n. 39). O diálogo é também testemunho de Cristo, exigindo equilíbrio - abertura, acolhida, imparcialidade e cooperação (CONGREGAÇÃO PARA A EVANGELIZAÇÃO DOS POVOS; PONTIFÍCIO CONSELHO PARA O DIÁLOGO INTER-RELIGIOSO, 1991, n. 
47) - e uma firme convicção religiosa - "isto não significa que [...] devam ser postas de lado as próprias convicções religiosas. Pelo contrário, a sinceridade do diálogo inter-religioso exige que se entre nele com a integralidade da própria fé" (CONGREGAÇÃO PARA A EVANGELIZAÇÃO DOS POVOS; PONTIFÍCIO CONSELHO PARA O DIÁLOGO INTER-RELIGIOSO, 1991, n. 48). Por fim, supõe abertura à verdade, disposição aos valores positivos.

Diálogo e Anúncio trata do diálogo inter-religioso a partir da unidade da salvação e da abertura às religiões, o que explicita a "presença operante do mistério de Jesus Cristo para além dos confins visíveis da Igreja" (CONGREGAÇÃO PARA A EVANGELIZAÇÃO DOS POVOS; PONTIFÍCIO CONSELHO PARA O DIÁLOGO INTER-RELIGIOSO, 1991, n. 50).

\section{Evangelização e pluralismo religioso na escola católica}

Como educar e evangelizar em diálogo em um contexto de pluralismo religioso? Como resposta, articulam-se os contextos e os conceitos apresentados, discutindo os principais desafios e alguns possíveis caminhos.

\section{Questões desafiadoras}

Um primeiro desafio diz respeito ao caráter tecnicista do currículo, que preconiza em absoluto: ensino, aprendizagem, avaliação, método, eficiência e objetivos. Trata-se de uma educação cujo ideal é o progresso, e o objetivo é a formação de profissionais eficientes pela via da técnica. Sua teleologia é socioeconômica e pragmática.

A sobreposição do cognitivo ao afetivo e dos conhecimentos e das competências à relação com o saber pode levar à negatividade das experiências religiosas, que deixam de mobilizar o diálogo e articular os valores e os sentidos do Evangelho com a vida. Que diálogo há entre as expressões religiosas em um currículo enclausurado na razão técnica, comprometida unicamente com o sucesso acadêmico e profissional?

Um segundo desafio: uma compreensão equivocada da ação educativo-evangelizadora com interlocutores de diferentes crenças ou que rejeitam a experiência religiosa até a negação de Deus. No projeto educativo-evangelizador, os fundamentos do diálogo inter-religioso subjazem às epistemologias dos componentes curriculares. Por isso, todo o currículo está aberto ao diálogo. O desafio está nos reducionismos e na inadequada compreensão acerca do diálogo inter-religioso, que pode levar à consideração de que apenas o Ensino Religioso é espaço para tal diálogo, por tratar do tema religião, ou de que o diálogo inter-religioso é uma modalidade de Catequese ou mesmo justaposição de crenças. 
[...] os projetos educativos, também aqueles assumidos em perspectiva confessional, são salutarmente desafiados a considerar a pluralidade religiosa como elemento constitutivo e potencializador de sua missão. Particularmente em relação à escola católica, esta tarefa não se resume a uma simples opção feita no plano pedagógico, mas vincula-se à sua natureza eclesial, desembocando no projeto de evangelização assumido pela mesma (COLET; WOLFF, 2015, p. 430).

Por fim, há o desafio de educar para a espiritualidade. Na perspectiva cristã, espiritualidade "é a fé feita experiência” (BOFF, 2015, p. 377). É a relação de amor e comunhão entre Deus e o homem. A ação educativo-evangelizadora se funda nessa espiritualidade, que indica a transcendência como essencial à fé, relação pessoal com o Deus revelado em Cristo. As experiências de transcendência marcam também as religiões. O Concílio Vaticano II afirma que os membros das religiões se indagam:

[...] que é ser homem ou mulher? Qual é o fim da vida? Que é bem e que é mal? De onde vêm a dor e o sofrimento? Que sentido têm? Qual o caminho para alcançar a verdadeira felicidade? [...] Enfim, qual é o mistério final de nossa existência? De onde viemos e para onde vamos? (CONCÍLIO ECUMÊNICO VATICANO II, 1965, n. 1).

Nesse sentido, a espiritualidade integra o diálogo inter-religioso. $\mathrm{Na}$ escola católica, trata-se a espiritualidade como restrita às comunidades religiosas ou ao indivíduo ou é posta em diálogo, inclusive entre os sujeitos arreligiosos?

Itinerários educativo-evangelizadores: vias para um diálogo inclusivo

Os caminhos (vias) para o diálogo evangelizador na escola católica quanto ao pluralismo religioso se constituem na relação entre a prática do diálogo e os fundamentos do diálogo inter-religioso. Tais vias são itinerários de educação e evangelização, que, no campo do diálogo inter-religioso, são metodologias amplamente consolidadas, perfeitamente aplicáveis ao âmbito educacional.

1) Via antropológica. É o caminho da pessoa. Na tradição cristã, a pessoa humana é Imago Dei. Sua dignidade está nesse princípio fundamental. Por isso, no centro da missão eclesial está o ser humano, que ocupa lugar proeminente no plano da criação e da redenção. Nesse sentido, o anúncio de Cristo e a afirmação da dignidade humana, sua promoção ${ }^{9}$ e seu desenvolvimento inte$\operatorname{gral}^{10}$ são indissociáveis. No que tange ao diálogo, Nostra Aetate (n. 5) explicita esse posicionamento ao concluir seu texto indicando a fraternidade universal e a reprovação de toda discriminação racial ou religiosa como motivações e efeitos do diálogo entre as religiões. 
Nesse sentido, há a via antropológica como caminho de diálogo na escola, especialmente no âmbito do currículo. Se todo currículo expressa uma visão de mundo fundada em uma concepção de ser humano, o currículo evangelizador tem como base a perspectiva humanista cristã, que dialoga com as perspectivas antropológicas das expressões religiosas.

Uma comunidade escolar, que se baseia em valores da fé católica, traduz na sua organização e no seu currículo a visão personalista própria da tradição humanista cristã, não em contraposição, mas em diálogo com as outras culturas e crenças religiosas. [...]. A sua característica confessional não deve constituir uma barreira, mas ser condição de diálogo intercultural, ajudando cada aluno a crescer em humanidade, responsabilidade civil e na aprendizagem (CONGREGAÇÃO PARA A EDUCAÇÃO CATÓLICA, 2014, n. 6).

A via antropológica, segundo Colet e Wolff (2015), é a via da relação e da integridade do sujeito. Um dos motivos do diálogo entre as religiões no campo educativo é o reconhecimento do mistério do ser humano em consonância com o mistério de Deus (CONGREGAÇÃO PARA A EDUCAÇÃO CATÓLICA, 2013, n. 13). Para esse reconhecimento, não há que se abdicar de sua identidade religiosa. Nesse contexto, o currículo aponta o significado único de Jesus Cristo para o ser humano, em diálogo com os valores positivos das religiões.

O diálogo pela via antropológica pode contemplar propostas que: privilegiam o lugar e o papel da pessoa nos objetivos educacionais; viabilizam tempo e espaço para a reflexão sobre a condição humana; propõem atividades-problema sobre as diversas concepções de ser humano; motivam os sujeitos à partilha sobre a relação ser humano-religião sob o ponto de vista das experiências e dos valores.

2) Via ética. Privilegia a ação humana em relação à caminhada comum dos homens e das mulheres nas esferas política, social, ecológica, religiosa. Daí emergem algumas questões candentes: diferença, tolerância, paz, justiça, cuidado, respeito. $\mathrm{Na}$ tradição cristã, as dimensões antropológica e ética estão imbricadas, pois fazem referência ao princípio da dignidade humana. Entretanto, a via ética destaca a ação humana como promotora de transformação, paz, fraternidade e solidariedade.

Cada sistema ético tem seus fundamentos em conceitos e pressupostos que, em um esquema complexo e orgânico, constituem o conjunto de seus valores. Isso vale também para as religiões e demais expressões religiosas, em maior ou menor grau. As experiências originárias e os elementos fundantes das religiões explicitam sentidos e significados que, traduzidos para o âmbito da ação humana, resultam em uma ética própria. Justifica-se, por isso, falar de ética cristã, ética judaica, ética budista. O diálogo, portanto, fundamenta-se na vivência e na partilha dos valores ético-religiosos. As diferentes posições são contrastadas com os valores universais ou os ideais de uma convivência e uma sociedade autenticamente humanas. 
No projeto educativo-evangelizador, a ética cristã é caminho para o diálogo, na medida em que a categoria Reino de Deus contempla a vivência da justiça, da paz, da fraternidade e da caridade como critérios para a construção da civilização do amor. O Reino de Deus é o próprio Jesus Cristo, paradigma do diálogo pelo caminho da ética. Nesse sentido, afirma o Documento de Aparecida:

[...] o diálogo inter-religioso, além de seu caráter teológico, tem significado especial na construção da nova humanidade: abre caminhos inéditos de testemunho cristão, promove a liberdade e dignidade dos povos, estimula a colaboração para o bem comum, supera a violência motivada por atitudes religiosas fundamentalistas, educa para a paz e para a convivência cidadã (CELAM, 2008, p. 239).

Na prática, dá-se quando se relacionam objetivos educacionais, conteúdos e valores, isto é, conhecimento e vida social. A pretensa busca pela neutralidade nem sempre é válida, pois o processo de aprendizagem exige escolhas, posicionamentos e valorações. O salutar diálogo entre as expressões religiosas ilumina esse processo a partir dos posicionamentos éticos, da disponibilidade recíproca em acolher o outro, do respeito e da confiança, das convicções e da busca por ideais comuns. O contributo das religiões para a paz e para o bem comum torna-se efetivo quando se compreende que sua consecução está na cooperação e no "caminhar junto".

3) Via solidária. "Onde os cristãos e os outros colaboram em vista do desenvolvimento integral e da libertação da gente" (CONGREGAÇÃO PARA A EVANGELIZAÇÃOO DOS POVOS; PONTIFÍCIO CONSELHO PARA O DIÁLOGO INTER-RELIGIOSO, 1991, n. 42). A via solidária é ativa, programática, interconfessional ou interinstitucional e se atualiza em espaços específicos, como o dos direitos humanos, da justiça social, da ecologia e das políticas públicas. É aí que as expressões religiosas encontram alternativas para a superação dos desafios e dos males que atingem especialmente as pessoas mais vulneráveis e empobrecidas. Funda-se no serviço ao outro e tem sua efetividade garantida em virtude de seu caráter programático.

Também no diálogo das obras afirma-se Jesus Cristo como modelo para a vivência da solidariedade. Seu ministério teve como centro o pequeno, o pobre, o esquecido, não como opção excludente, mas preferencial, tal como as Conferências Gerais do Episcopado Latino-Americano ${ }^{11}$ e o Magistério recente têm expressado. O Papa Bento XVI (2007) afirmou: "a opção preferencial pelos pobres está implícita na fé cristológica naquele Deus que se fez pobre por nós, para enriquecer-nos com a sua pobreza". A via solidária é um imperativo, pois, a exemplo de Cristo, todos são chamados a defender e promover a dignidade humana com palavras e obras. 
Toda a dinâmica escolar deve estabelecer diálogos, iniciativas, programas e projetos pautados na dimensão da alteridade e da solidariedade: tudo o que atenta contra o desenvolvimento integral da pessoa exige de uma atuação solidária efetiva. Muitas instituições têm em seus projetos educativos e em seus currículos espaços e tempos para o diálogo, a organização e a execução de ações de educação para a solidariedade. Fomentar o diálogo inter-religioso nesse contexto e compreendê-lo como pressuposto da educação solidária é potencializar a cooperação entre as religiões como caminho para uma nova sociedade. O processo evangelizador, portanto, está centrado na relação fé e vida, que projeta para o diálogo e para a transformação da realidade.

4) Via espiritual. É um autêntico caminho de educação à transcendência. $\mathrm{Na}$ escola católica que evangeliza incluindo, a espiritualidade cristã destaca-se como fundamento do projeto de educação e evangelização e como abertura sincera ao outro pelo reconhecimento da pessoa como imagem e semelhança de Deus.

[...] uma educação para o diálogo inter-religioso ou interconfessional - que inclua também os que se assumem como ateus - terá de levar o educando a perceber a riqueza e o privilégio de se viver em um mundo que transborda sua experiência de transcendente em várias tradições espirituais (SOARES, 2012, p. 246).

A via espiritual, ou o diálogo da experiência religiosa, caracteriza-se pela abertura ao transcendente, "onde pessoas radicadas nas próprias tradições religiosas compartilham as suas riquezas espirituais [...] no que se refere à oração e à contemplação, à fé e aos caminhos da busca de Deus e do Absoluto" (CONGREGAÇÃO PARA A EVANGELIZAÇÃO DOS POVOS; PONTIFÍCIO CONSELHO PARA O DIÁLOGO INTER-RELIGIOSO, 1991, n. 42). Essa abertura diz das perguntas fundamentais sobre os sentidos que orientam a existência, dado que a ciência não possui todas as respostas para tal. Logo, o diálogo da experiência religiosa é um caminho fecundo para a dinâmica curricular evangelizadora, pois:

O esforço do conhecimento e da pesquisa não deve ser separado do sentido ético e do transcendente. Nenhuma ciência verdadeira pode negligenciar as suas consequências éticas e não existe verdadeira ciência que afaste da transcendência. [...] ciência e transcendência não se excluem reciprocamente, mas se conjugam para uma maior e melhor compreensão do homem e da realidade do mundo (CONGREGAÇÃO PARA A EDUCAÇÃO CATÓLICA, 2014, n. 2).

As diferentes tradições religiosas podem contribuir, a partir de suas experiências de transcendência, com o equilíbrio entre intuição e conceito, entre fé e razão. Tanto a espiritualidade cristã pode enriquecer as demais experiências de transcendência como estas podem favorecer uma espiritualidade cristã mais 
integral; e ambas propiciam um diálogo no qual todos, também os não crentes e ateus, podem perceber a relevância da transcendência como experiência humana de sentido e com o Absoluto. Em uma instituição educativa que acolhe o pluralismo como riqueza, sem comprometer sua identidade evangelizadora, a proposta pedagógico-pastoral pode e deve sistematizar processos de educação para a transcendência. Propostas que vinculam conhecimentos a sentidos são caminhos para o diálogo na via espiritual, pois evidenciam o olhar de contemplação para a realidade, a sacralidade da vida, a conexão homem-natureza, as práticas religiosas, a oração.

5) Via convivial. O diálogo da vida é de pessoa a pessoa; ocasional e permanente; próximo e afetivo. Tradução atual dessa via é a cultura do encontro, sobre a qual o Papa Francisco (2013a) afirmou na XXVIII Jornada Mundial da Juventude: "O encontro e o acolhimento de todos, a solidariedade [...] e a fraternidade são elementos que tornam a nossa civilização verdadeiramente humana. Temos de ser servidores da comunhão e da cultura do encontro". Em outra ocasião, disse:

Para que haja diálogo, é necessária uma base fundamental, uma identidade. [...]. Além disso o diálogo pressupõe e exige de nós esta cultura do encontro. Ou seja, um encontro que sabe reconhecer que a diversidade não só é boa, mas necessária. [...]. Eu levo aquilo que é meu e vou escutar aquilo que o outro diz; aquilo que me enriquece no outro [...] (PAPA FRANCISCO, 2015).

A cultura do encontro é expressão de um diálogo autêntico e aberto, para um enriquecimento mútuo, do qual a fraternidade e a comunhão são os efeitos visíveis. "Este diálogo é, em primeiro lugar, uma conversa sobre a vida humana ou simplesmente - [...] - 'estar aberto a eles, compartilhando as suas alegrias e penas” (PAPA FRANCISCO, 2013b, p. 187, n. 250). Não necessita de espaço formal/institucional; não possui agenda prévia; e não busca outros objetivos que não o próprio diálogo e a partilha de vida.

Por si só, a dinâmica educacional favorece o encontro e o diálogo. O convívio e a troca de experiências estão imbricados nos processos escolares. Dado que o cotidiano escolar é também contexto e experiência, potencializa-se a cultura do encontro quando o mesmo cotidiano torna tangível sua parte vazia, ou seja, o que não é planejável, controlável, mas que é vida, afeto, partilha, percepção, amizade, sentimento. Se isso acontece no âmbito da experiência religiosa, tem-se um movimento contínuo que favorece o diálogo inter-religioso também na esfera do não formal. Em suma, o diálogo da vida assume importância cada vez maior na escola católica quando é valorizado e percebido pelos sujeitos do projeto educativo-evangelizador como meio privilegiado de formação integral, educação e evangelização. 


\section{Considerações finais}

Reitera-se, em primeiro lugar, a complexidade do cenário religioso contemporâneo, marcado pela pós-secularização e pelo retorno do religioso sob formas privadas. É certo que hoje não se parte da aceitação universal do cristianismo para educar e evangelizar. Porém, é possível se sentir impelido a ressignificar a mensagem cristã, a fim de que ofereça respostas às contradições pós-modernas.

Em segundo lugar, tem-se que o diálogo inter-religioso se fundamenta na verdade cristã como abertura ao diálogo. Especialmente a partir do Concílio Vaticano II, a Igreja afirma o caráter positivo das religiões e não entende ser detentora da salvação, mas servidora de Cristo, que salva a todos. Por isso, anuncia a Cristo, em diálogo, expressando a riqueza e a profundidade do amor de Deus pela humanidade.

Tais constatações levam as instituições educacionais católicas a constituir um projeto educativo-evangelizador que não só acolhe a diversidade religiosa como a percebe essencial aos seus processos. Isso fica evidente quando se trata a questão religiosa como dimensão de diálogo e anúncio, oportunizando um diálogo efetivo por diversos caminhos, tendo o evento Cristo como abertura para tal. Portanto, o diálogo evangelizador e inclusivo é possível porque tem a categoria de diálogo inter-religioso como subjacente a seu movimento.

Situando-se como educador católico, reconhece-se a urgente necessidade formativa dos agentes de pastoral que atuam no âmbito da educação acerca do tema em questão. Parece que o tema do diálogo inter-religioso ainda não foi suficientemente valorizado na reflexão e prática pastorais, ainda que seja praticamente unânime a percepção de que todos estão imersos em um contexto plural que reclama uma resposta significativa da educação católica. Nesse sentido, o presente artigo deseja contribuir com uma reflexão da qual depende o futuro da educação católica em relação ao pluralismo hodierno: a realidade do diálogo inter-religioso implica identidade e abertura. Identidade diz respeito à clareza dos fundamentos institucionais, como Igreja e escola católica; abertura se refere à atitude de deixar-se enriquecer pelas diferentes expressões religiosas, que possibilitam visualizar novos e significativos aspectos do Evangelho. Apenas assim será possível se afirmar como evangelizador no contexto contemporâneo.

Recebido em: 18/02/2019

Revisado pelo autor em: 08/05/2019 Aceito para publicação em: 24/05/2019

\section{Notas}

1 Mestrado em Teologia pela Pontifícia Universidade Católica do Paraná (PUC-PR) (2017), na linha de pesquisa Bíblia e Evangelização. Pós-graduação (em andamento) em Gestão Estratégica de Educação Básica pela PUC-PR (2018). Pós-graduado em Gestão de Processos Pastorais 
pela PUC-PR. Pós-graduado em Gestão de Pessoas pela Universidade Presbiteriana Mackenzie. Licenciatura Plena em Filosofia com habilitação em História pela Universidade Assunção. Tem experiência nas áreas de Filosofia, atuando nos temas relativos à Teologia Pastoral e Eclesiologia, e de Educação, atuando nos temas relativos à Educação Básica Confessional e Pastoral Escolar. E-mail: oresende@colegiosmaristas.com.br

2 Doutorando em Teologia pela Pontifícia Universidade Católica do Rio de Janeiro (2018), na área de Teologia Sistemático-Pastoral e linha de pesquisa Fé e Cultura. Mestre em Teologia pela Pontifícia Universidade Católica do Paraná (PUC-PR) (2017), na área de Teologia Sistemático-Pastoral e linha de pesquisa Teologia e Evangelização na Contemporaneidade. Especialista em Gestão de Processos Pastorais pela PUC-PR (2015). Bacharel e licenciado em Filosofia pela Universidade Federal do Paraná (2014). Dedica-se à pesquisa teológica das seguintes questões: Eclesiologia, Pneumatologia e Pastoral. Tem experiência nas áreas de Teologia Sistemática, com ênfase em Eclesiologia e Pneumatologia, de Filosofia, com ênfase em Filosofia Medieval, e de Educação, com ênfase em Pastoral Escolar. E-mail: diogopessotto@hotmail.com

3 Thomas Luckmann aborda o retorno do religioso na pós-modernidade em sua obra "A religião invisível" (1967). Para o sociólogo, a atitude do bricolage, no âmbito das emoções e dos sentimentos do indivíduo, é o que dá sustentação ao processo religioso de constituição da visão de mundo. 4 Esta e as demais citações idênticas constam em "A unicidade e a universalidade salvífica de Jesus Cristo em Jacques Dupuis e na Dominus Iesus”, pesquisa do Dr. Antonio Ferreira (2009, não publicada).

5 A exposição tematiza o diálogo inter-religioso, que discerne como a Graça de Deus opera no coração dos membros de outras tradições e como se pode atuar juntos no testemunho da verdade, da justiça, da paz, da promoção humana e do cuidado ambiental; tudo isso como missão, anúncio e testemunho de fé pela presença evangélica cristã. Já o ecumenismo é resposta ao dom da graça de Deus, que chama os cristãos à unidade em Cristo, no Espírito, com vistas à salvação de todos. 6 Esta e as demais citações idênticas constam em "Conheça o Documento Diálogo e Anúncio" (2014), do Prof. Dr. Marcial Maçaneiro, elaborado para a disciplina Diálogo Inter-Religioso e Multiculturalidade da Especialização em Gestão de Processos Pastorais, da PUC-PR. O material não publicado.

7 Nostra Aetate, Dei Verbum, Unitatis Redintegratio e Dignitatis Humanae.

8 Evangelii Nuntiandi, Redemptor Hominis, Dominum et Vivificantem e Redemptoris Missio.

9 Cf. Evangelii Nuntiandi (1975) e Evangelii Gaudium (2013).

10 Cf. Gaudium et Spes (1965), Populorum Progressio (1967) e Sollicitudo Rei Socialis (1987).

11 Medellín (1968), Puebla (1979), Santo Domingo (1992) e Aparecida (2007).

\section{Referências}

BOFF, Clodovis Maria. Espiritualidade e pastoral. Sugestões para a pastoral da educação. Revista Eclesiástica Brasileira, Petrópolis, v. 75, n. 298, p. 369389, abr./jun. 2015.

COLET, Raquel de Fátima; WOLFF, Elias. A dimensão ecumênica e inter-religiosa da Pastoral Escolar na Escola Católica: Fundamentos teológicos e horizontes para a ação. In: CONGRESSO NACIONAL DE EDUCAÇÃO CATÓLICA, 3., 2015, Curitiba. Anais... Brasília: ANEC, 2015. p. 429-440. CONCÍLIO ECUMÊNICO VATICANO II. Declaração Nostra Aetate. Sobre a Igreja e as religiões não-cristãs. Roma, 28 out. 1965. Disponível em: 
http://www.vatican.va/archive/hist_councils/ii_vatican_council/documents/ vat-ii_decl_19651028_nostra-aetate_po.html. Acesso em: 5 jan. 2019.

Paulinas, 2004

Decreto Unitatis Redintegratio. Sobre o ecumenismo. São Paulo:

. Vaticano II: mensagens, discursos e documentos. 2. ed. São Paulo:

Paulinas, 2007.

CELAM - Conferência Episcopal Latino-Americana. Documento de Aparecida: texto conclusivo da V Conferência Geral do Episcopado Latino-Americano e do Caribe. 7. ed. São Paulo: Paulinas; Paulus; Brasília: CNBB, 2008.

CONGREGAÇÃO PARA A EDUCAÇÃO CATÓLICA. Educar al diálogo intercultural en la escuela católica. Vivir juntos para una civilización del amor. Roma, 28 out. 2013. Disponível em: http://www.vatican.va/ roman_curia/congregations/ccatheduc/documents/rc_con_ccatheduc_ doc_20131028_dialogo-interculturale_sp.html. Acesso em: 5 jan. 2019.

. Instrumentum Laboris Educar hoje e amanhã, uma paixão que se renova. Vaticano, 7 abr. 2014. Disponível em: http://www.vatican. va/roman_curia/congregations/ccatheduc/documents/rc_con_ccatheduc_ doc_20140407_educare-oggi-e-domani_po.html. Acesso em: 5 jan. 2019.

CONGREGAÇÃO PARA A EVANGELIZAÇÃO DOS POVOS; PONTIFÍCIO CONSELHO PARA O DIÁLOGO INTER-RELIGIOSO. Diálogo e Anúncio. Roma, 19 maio 1991. Disponível em: http://www.vatican. va/roman_curia/pontifical_councils/interelg/documents/rc_pc_interelg_ doc_19051991_dialogue-and-proclamatio_po.html. Acesso em: 5 jan. 2019.

FERREIRA, Antonio. A unicidade e a universalidade salvífica de Jesus Cristo em Jacques Dupuis e na Dominus Iesus. [s.l.: s.n.], 2009. (não publicado).

LIBÂNIO, João Batista. O Sagrado na Pós-Modernidade. In: CALIMAN, Cleto (org.). A sedução do sagrado: o fenômeno religioso na virada do milênio. Petrópolis: Vozes, 1998. p. 61-78.

LUCKMANN, Thomas. A religião invisível. São Paulo: Edições Loyola, 1967.

MAÇANEIRO, Marcial. Conheça o Documento Diálogo e Anúncio. [s.l: s.n.], 2014. (não pulicado).

MARRAMAO, Giacomo. Céu e terra. São Paulo: UNESP, 1994.

MARTELLI, Stefano. A religião na sociedade pós-moderna: entre secularização e dessecularização. Tradução de Euclides Martins Balancin. São Paulo: Paulinas, 1995.

MIRANDA, Mario de França. O encontro das religiões. Perspectiva Teológica, Belo Horizonte, v. 26, n. 68, p. 9-26, jan./abr. 1994. 
A Igreja numa sociedade fragmentada. Escritos eclesiológicos. São Paulo: Loyola, 2006.

MÓNICO, Lisete dos Santos Mendes. Secularização, (a)teísmo e pluralismo religioso nas sociedades ocidentais contemporâneas. Horizonte, Belo Horizonte, v. 13, n. 40, p. 2064-2095, out./dez. 2015.

PAPA BENTO XVI. Discurso na Sessão Inaugural dos Trabalhos da V Conferência Geral do Episcopado da América Latina e do Caribe. Santuário de Aparecida, 13 maio 2007. Disponível em: https://w2.vatican. $\mathrm{va} /$ content/benedict-xvi/pt/speeches/2007/may/documents/hf_ben-xvi_ spe_20070513_conference-aparecida.html. Acesso em: 5 jan. 2019.

PAPA FRANCISCO. Santa Missa com os Bispos da JMJ, Sacerdotes, Religiosos e Seminaristas. Visita Apostólica do Papa Francisco ao Brasil por ocasião da XXVIII Jornada Mundial da Juventude. Catedral de São Sebastião, Rio de Janeiro, 27 jul. 2013a. Disponível em: http://w2.vatican.va/content/ francesco/pt/homilies/2013/documents/papa-francesco_20130727_gmg-omelia-rio-clero.html. Acesso em: 5 jan. 2019.

. Exortação Apostólica Evangelii Gaudium do Santo Padre Francisco ao Episcopado, ao Clero, às Pessoas Consagradas e aos Fiéis Leigos sobre o Anúncio do Evangelho no Mundo Actual. Vaticano: Tipografia do Vaticano, 2013b.

. Encontro com os Representantes da Sociedade Civil. Viagem apostólica do Papa Francisco ao Equador, Bolívia e Paraguai. Estádio León Condou da Escola São José, Assunção (Paraguai), 11 jul. 2015. Disponível em: http://w2.vatican.va/content/francesco/pt/speeches/2015/july/documents/papa-francesco_20150711_paraguay-societa-civile.html. Acesso em: 5 jan. 2019.

PAPA JOÃO PAULO II. Carta encíclica Dominum et Vivificantem. Sobre o Espírito Santo: na vida da igreja e do mundo. Roma, 18 maio 1986.

SANCHEZ, Wagner Lopes. Pluralismo religioso: as religiões no mundo atual. 2. ed. São Paulo: Paulinas, 2010.

SOARES, Afonso Maria Ligorio Soares. Educação e pluralidade religiosa. In: FIGUEIRA, Eulálio; JUNQUEIRA, Sérgio. Teologia e Educação: educar para a caridade e a solidariedade. São Paulo: Paulinas, 2012. p. 230-255.

TOURAINE, Alain. Crítica da modernidade. 4. ed. Petrópolis: Vozes, 1997.

USARSKI, Frank. Nostra Aetate. In: PASSOS, João Décio; SANCHEZ, Wagner (coord.). Dicionário do Concílio Vaticano II. São Paulo: Paulinas, 2015. p. 666-671. 